\title{
Influence of SiC Production Temperature on Its Physicochemical Characteristics
}

T. Tkachenko ${ }^{1}$, V. Yevdokymenko ${ }^{1}$, D. Kamenskyh ${ }^{1}$, V. Povazhny ${ }^{1}$, M. Filonenko ${ }^{2}$, V. Kremenetskii ${ }^{3}$, V. Vakhrin ${ }^{4}$, and V. Kashkovsky ${ }^{1}$

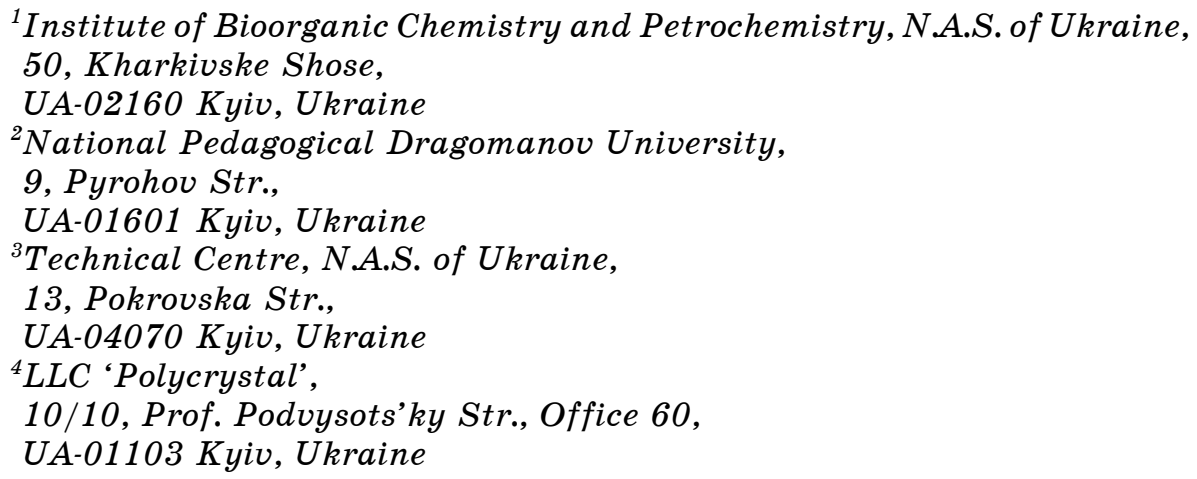

Silicon carbide, due to unique physicochemical properties (thermal and chemical stability, oxidation and corrosion resistance, high hardness, resistance to radiation damage), is used to produce oxygen-free ceramics, semiconductors, Schottky diodes, UV sensors, covering of the spaceship hull, and for the fusion reactor wall. Dependent on the way and obtaining condition, some properties of the silicon carbide are changed. In this paper, $\mathrm{SiC}$ with morphologies of both particles and whiskers is grown by a direct carbothermal reduction for a shorter holding time of $1 \mathrm{~h}$ at $1400-1900^{\circ} \mathrm{C}$. Effects of process conditions on the phase composition and morphology of the samples are investigated using XRF, XRD, FTIR-ATR and SEM-EDS, respectively. The XRD results show that the final product is identified as $\beta$-SiC having lattice parameter $a=4.3365-4.3575 \AA$ that is in close agreement with the reported value of 4.3589 $\AA$. The thickness of the SiC whiskers is increased with the growth of temperature. The results obtained also show that the characteristics of the synthesised SiC particles strongly depend on the heat-treatment conditions.

Карбід кремнію завдяки своїм унікальним фізико-хемічним властивостям (термо- та хемічній стійкості, стійкості до окиснення та корозії, високій твердості, радіяційній стійкості) застосовується для виготовлення безкисневої кераміки, напівпровідників, діодів Шотткі, УФ-датчиків, покриття 
корпусів космічних кораблів і при виготовленні стінок термоядерних реакторів. Залежно від способу й умов одержання деякі властивості карбіду кремнію змінюються. У цій роботі вирощували $\mathrm{SiC}$ як у вигляді частинок, так і віскерів шляхом прямої карботермальної синтези із часом контакту в 1 год. при 1400-1900 ${ }^{\circ} \mathrm{C}$. Вплив умов процесу на фазовий склад і морфологію зразків досліджували з використанням, відповідно, рентгенофлюоресцентної аналізи, РФА, інфрачервоної спектральної аналізи Фур'є із перетворенням і CEM-ЕДА. Результати РФА показали, що кінцевий продукт був ідентифікований як $\beta$-SiC, що має параметер гратниці $a=4,3365-$ $4.3575 \AA$, що узгоджується з літературним значенням $4,3589 \AA$. Товщина віскерів $\mathrm{SiC}$ збільшувалася зі зростання температури. Одержані результати також показали, що характеристики синтезованих частинок $\mathrm{SiC}$ сильно залежать від умов термічного оброблення.

Key words: silicon carbide, carbothermal reduction, silicon dioxide, whiskers, heat treatment conditions.

Ключові слова: карбід кремнію, карботермічне відновлення, діоксид кремнію, віскери, умови термічного оброблення.

(Received 4 December, 2019)

\section{INTRODUCTION}

Silicon carbide due to its unique properties (high melting point, chemical and radiation resistance) has been widely used in the nuclear industry, microelectronics, as an abrasive material with high microhardness, in the jewellery industry, for the manufacture of refractories, in the contexture of composite materials, for melting silicon technical purity and so on $[1,2]$. The operation, in many cases, in the extreme conditions of modern devices (in particular, radio electronics) puts more severe conditions on the relevant products and, above all, on increasing their efficiency. Devices made of silicon carbide are capable of operating efficiently under high temperatures (up $\left.600^{\circ} \mathrm{C}\right)$ under conditions of high ionizing radiation [3].

There are approximately 250 crystalline forms of silicon carbide (polytype) compounds having similar crystalline structures [4]. The mechanism of formation and thermodynamic stability of different polytypes have not been fully investigated and depend on the temperature conditions, the amount and nature of the impurities, the nature of the gas atmosphere in which the synthesis is carried out, the conditions for the kinetic growth of a single crystal of silicon carbide [5].

The unique properties of silicon carbide lead to an intensive search for ways to improve the technological aspects of both obtaining the original material and the final product with the necessary physical and chemical properties. It should be emphasised that publications of re- 
cent years are focused on fundamental and applied aspects, which are aimed at the development of existing developments in silicon carbide and, in particular, the mechanism of its production, the speed of the stages of synthesis reactions, the influence of various factors on the formation of the final product, etc. [2,6-12]. The aim of our work was the investigation of heat treatment on the silicon carbide obtaining.

\section{EXPERIMENTAL DETAILS}

High pure $\mathrm{SiO}_{2}$ was obtained in our department by the method described in [13]. Activated carbon was purchased from Farmak, Ukraine. They were mixed to uniformity, and the mixture was placed at the bottom of a graphite crucible. The air-dried mixture was converted to silicon carbide in VCI-3.5 furnace under a vacuum and argon atmosphere. The configuration of the reaction oven is shown in Fig. 1. After the evacuation of furnace chamber to about 950 mbar, argon gas was introduced at a flowing rate range of $6-12 \mathrm{l} / \mathrm{h}$ during the overall experiment. Silica and carbon were converted into $\mathrm{SiC}$ at different reaction temperatures $1400-1900^{\circ} \mathrm{C}$ for 1 hour using a one-step heating cycle in a furnace with the heating of $10^{\circ} \mathrm{C} / \mathrm{min}$. After the reaction, the temperature was allowed to cool down to room temperature with a controlled cooling of $20^{\circ} \mathrm{C} / \mathrm{min}$. The products were purified by treating at $800^{\circ} \mathrm{C}$ in intervals of 30 min muffle oven in the air to remove residual carbon. Obtained $\mathrm{SiC}$ exhibited a colour varying from grey to light green, which was related to the temperatures of synthesis.

Silicon and other components in raw materials and obtained carbides were analysed by Expert 3L XRF analyser. The scanning electron microscopy (SEM) images were taken using JSM e 6490LV JEOL micro-

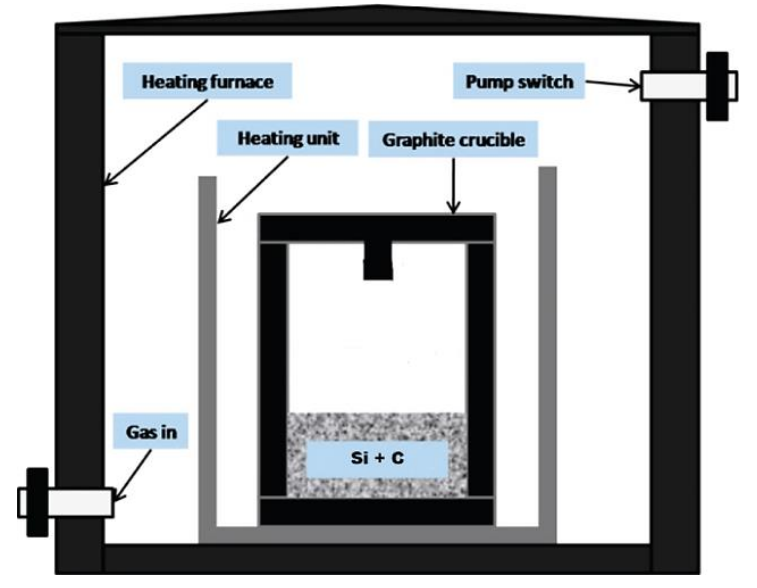

Fig. 1. Configuration of the reaction oven. 
scope working at $20.0 \mathrm{kV}$ with energy dispersion spectroscopy (EDS, attached to the SEM). The phase identification of the products was examined by under x-ray diffraction (XRD) using a MiniFlex 300/600 diffractometer (Rigaku, Japan). The diffraction patterns were recorded using $\mathrm{Cu} K_{\alpha}$ radiation $(\lambda=1.5418 \AA$ ), the operating voltage of $40 \mathrm{kV}$ and current of $15 \mathrm{~mA}$. XRD pattern of samples was obtained in the $2 \theta$ range between $10^{\circ}$ and $85^{\circ}$ with a step of $0.02^{\circ}$. FTIR analysis of the obtained MCC was performed using IRAffinity-1S FTIR spectrometer (Shimadzu, Japan) equipped with a Quest ATR Diamond GS-10800X (Specac, UK) within the wavenumber range of 4000 to $400 \mathrm{~cm}^{-1}$. The porous properties of the prepared carbides were characterized using $\mathrm{N}_{2}$ adsorption at $-195.8^{\circ} \mathrm{C}$ on a specific surface area and porosity analyser Nova 1200e (Quantachrome, USA).

\section{RESULTS AND DISCUSSION}

Major mineral and trace elements in raw materials and prepared carbides at different temperatures were determined via XRF (Table 1). Initial silica was high pure $\left(\mathrm{SiO}_{2}\right.$ content-99.994\% mass.). Draws at-

TABLE 1. XRF analysis of raw materials and obtained SiC.

\begin{tabular}{|c|c|c|c|c|c|c|c|c|}
\hline \multirow{2}{*}{ 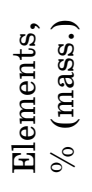 } & \multirow[b]{2}{*}{$\mathrm{SiO}_{2}$} & \multirow[b]{2}{*}{$\mathrm{C}$} & \multicolumn{6}{|c|}{$\mathrm{SiC}$} \\
\hline & & & $1400^{\circ} \mathrm{C}$ & $1500^{\circ} \mathrm{C}$ & $1600^{\circ} \mathrm{C}$ & $1700^{\circ} \mathrm{C}$ & $1800^{\circ} \mathrm{C}$ & $1900^{\circ} \mathrm{C}$ \\
\hline$\overline{\mathrm{Al}}$ & & 1.45 & & & & & & \\
\hline $\mathrm{Si}$ & 46.74 & 11.80 & 46.20 & 68.34 & 69.95 & 70.04 & 70.04 & 70.04 \\
\hline $\mathrm{P}$ & & 5.54 & & & & & & \\
\hline $\mathrm{S}$ & & 1.90 & & & & & & \\
\hline K & & 6.75 & & & & & & \\
\hline $\mathrm{Ca}$ & & 29.95 & 0.77 & 0.63 & & & & \\
\hline $\mathrm{Ti}$ & & 0.48 & & & & & & \\
\hline $\mathrm{Mn}$ & & 0.17 & & & & & & \\
\hline $\mathrm{Fe}$ & ppm 39 & 2,79 & 0.06 & 0.05 & & & & \\
\hline $\mathrm{Ni}$ & & ppm 320 & & & & & & \\
\hline $\mathrm{Cu}$ & & ppm 374 & & & & & & \\
\hline $\mathrm{Zn}$ & & 0.11 & & & & & & \\
\hline $\mathrm{Sr}$ & & 0.06 & & & & & & \\
\hline $\mathrm{Zr}$ & & ppm 35 & ppm 14 & ppm 10 & & ppm 7 & ppm 9 & ppm 12 \\
\hline Mo & & ppm 67 & & & & & & \\
\hline $\mathrm{Ba}$ & & 0.09 & & & & & & \\
\hline
\end{tabular}


tention to the essential content of various elements in the initial carbon material. However, they are part of the ash residue, which is only $1.32 \%$ mass. The final products contain only major mineral Si, and not more than $0.1 \%$ of the trace $\mathrm{Ca}, \mathrm{Fe}$ and several ppms $\mathrm{Zr}$.

Figure 1 shows the XRD pattern of the initial silica and prepared $\mathrm{SiC}$ at different reacting temperatures. The $\mathrm{x}$-ray diffractogram of the powdered silicon shows characteristic features of amorphous materials (Fig. 2). With the increase of temperature, the peak intensity of $\beta$-SiC in the reduced samples became stronger, corresponding to the decrease

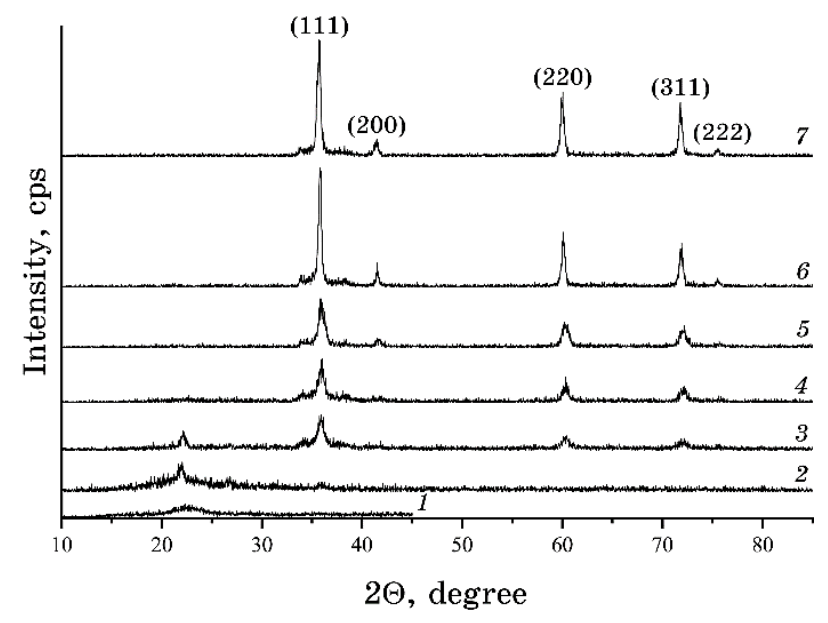

Fig. 2. XRD patterns of initial $\mathrm{SiO}_{2}(1)$ and obtained carbides for $1 \mathrm{~h}$ at different temperatures: $2-1400^{\circ} \mathrm{C}, 3-1500^{\circ} \mathrm{C}, 4-1600^{\circ} \mathrm{C}, 5-1700^{\circ} \mathrm{C}, 6-$ $1800^{\circ} \mathrm{C}, 7-1900^{\circ} \mathrm{C}$.

TABLE 2. Crystallographic data of $3 C$-SiC.

\begin{tabular}{|c|c|c|c|c|c|c|}
\hline Data & $1400^{\circ} \mathrm{C}$ & $1500^{\circ} \mathrm{C}$ & $1600^{\circ} \mathrm{C}$ & $1700^{\circ} \mathrm{C}$ & $1800^{\circ} \mathrm{C}$ & $1900^{\circ} \mathrm{C}$ \\
\hline Chemical formula & $\mathrm{SiO}_{2}$ & $\mathrm{SiC} / \mathrm{SiO}_{2}$ & $\mathrm{SiC} / \mathrm{SiO}_{2}$ & $\mathrm{SiC}$ & $\mathrm{SiC}$ & $\mathrm{SiC}$ \\
\hline Concentration, \% & 100 & $79 / 21$ & $94 / 6$ & 100 & 100 & 100 \\
\hline Crystal system & & $\begin{array}{c}\text { Cubic/ } \\
\text { /Tetragonal }\end{array}$ & $\begin{array}{c}\text { Cubic/ } \\
\text { /Tetragonal }\end{array}$ & Cubic & Cubic & Cubic \\
\hline Space group & & $\begin{array}{l}\text { 216: } F-43 m / \\
\text { /92: P41212 }\end{array}$ & $\begin{array}{l}\text { 216: } F-43 m / \\
\text { /92: P41212 }\end{array}$ & $\begin{array}{c}216: \\
F-43 m\end{array}$ & $\begin{array}{l}216: \\
F-43 m\end{array}$ & $\begin{array}{l}216: \\
F-43 m\end{array}$ \\
\hline \multicolumn{7}{|l|}{$\begin{array}{c}\text { Lattice } \\
\text { parameters, } \AA\end{array}$} \\
\hline$a$ & & $4.3365 / 4.9636$ & $4.3365 / 4$. & 4.341 & $4.347^{7}$ & 4.3575 \\
\hline$b$ & & $4.3365 / 4.9636$ & $4.3365 / 4.9636$ & 64.3415 & 4.3477 & 4.3575 \\
\hline$c$ & & $43365 / 6.9223$ & $4.3365 / 6.9223$ & 34.3415 & 4.3477 & 4.3575 \\
\hline$L, \mathrm{~nm}$ & & 11.48 & 11.86 & 11.98 & 29.47 & 22.17 \\
\hline
\end{tabular}


of silica peaks intensities. XRD analysis of the obtained carbides at $1500^{\circ} \mathrm{C}$ and $1600^{\circ} \mathrm{C}$ revealed that the product powder was mainly $\beta$-SiC together with a small fraction of $\mathrm{SiO}_{2}$ (Table 2). In the samples subjected to reduction until $1700^{\circ} \mathrm{C}$, only $\beta$-SiC was present. Prepared $\mathrm{SiC}$ particles have the same five characteristic diffraction peaks $\left(2 \theta=35.56^{\circ}, 41.06^{\circ}, 60.06^{\circ}, 71.84^{\circ}\right.$ and $\left.75.64^{\circ}\right)$ in the XRD patterns, confirming the pure $3 C$-SiC phase. A minor shift observed in the peak for $3 C$-SiC phase is caused by an increase in the lattice parameter $a$ due to an increase in temperature (Table 2). The value of $a$ obtained at $1900^{\circ} \mathrm{C}$ is in close proximity to the standard value $(a=4.3589 \AA)$ (JCPDS: 29-1129). The strong and sharp diffraction peaks indicate that the products are highly crystalline. The average crystallite sizes $(L)$ of the heat-treated samples calculated from the Selyakov-Scherrer equation by selecting the maximum intensity peak observed at $2 \theta=35.65^{\circ}$ for $3 C$-SiC are listed in Table 2 . Since the sample obtained at $1400^{\circ} \mathrm{C}$ was substantially amorphous in nature, no attempt was made to evaluate the crystallite size. The existence of a small peak at $2 \theta=34^{\circ}$ in the diffractogram for the reduction of the sample higher than $1500^{\circ} \mathrm{C}$ might be assigned to the diffraction of the crystal plane of $\alpha$-SiC. However, no other $\alpha$-SiC reflections are observed. A small peak $\left(2 \theta=34^{\circ}\right)$ can be ascribed to the stacking faults within the $3 C$-SiC structure (JCPDS: 29-1129) [5].

The FTIR spectrum of initial $\mathrm{SiO}_{2}$ and obtained carbides is shown in Fig. 3. The spectrum of the raw material shows typical adsorption

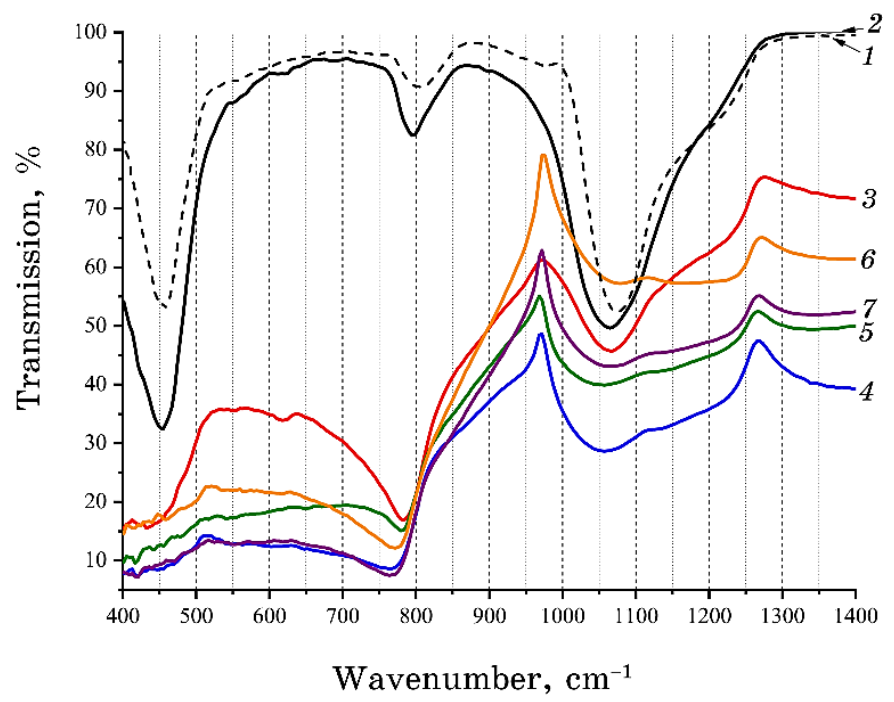

Fig. 3. FTIR spectra of initial $\mathrm{SiO}_{2}(1)$ and obtained carbides for $1 \mathrm{~h}$ at different temperatures: $2-1400^{\circ} \mathrm{C}, 3-1500^{\circ} \mathrm{C}, 4-1600^{\circ} \mathrm{C}, 5-1700^{\circ} \mathrm{C}, 6-$ $1800^{\circ} \mathrm{C}, 7-1900^{\circ} \mathrm{C}$. 
bands at 1074,800 and $457 \mathrm{~cm}^{-1}$. The vibrations' peaks are assigned to $\mathrm{Si}-\mathrm{O}-\mathrm{Si}$ asymmetric and $\mathrm{Si}-\mathrm{O}$ symmetric stretching modes [14] and the bending mode $\mathrm{Si}-\mathrm{O}-\mathrm{Si}$ as a weak band [15], respectively.

In Figure 3, it can be observed that synthesized $\mathrm{SiC}$ at $1400-1500^{\circ} \mathrm{C}$ have FTIR peak at 795 and $783 \mathrm{~cm}^{-1}$ corresponded to $\mathrm{Si}-\mathrm{C}$ symmetric stretching vibration and peaks near 1074 and $457 \mathrm{~cm}^{-1}$ indicating the existence of $\mathrm{SiO}_{2}$. As also indicated by both FTIR and XRD analysis, the $\mathrm{SiC}$ obtained at $1500^{\circ} \mathrm{C}$ contains a very small amount of silicon di-

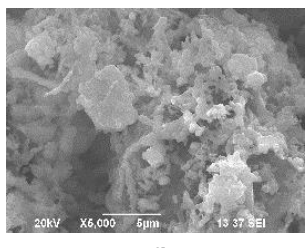

$a$



$e$
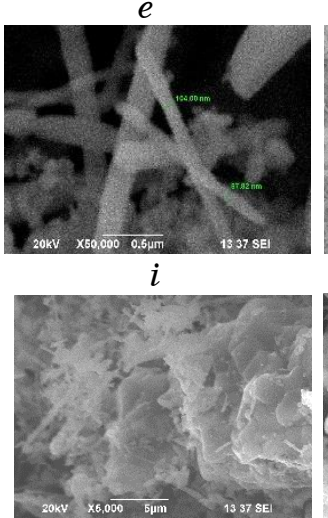

$m$

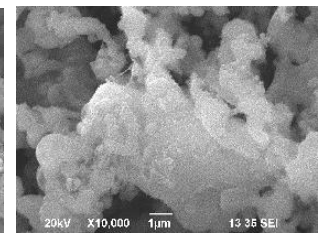

b

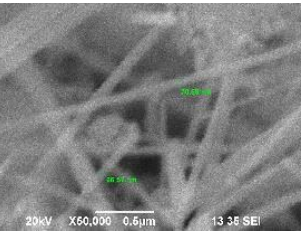

f

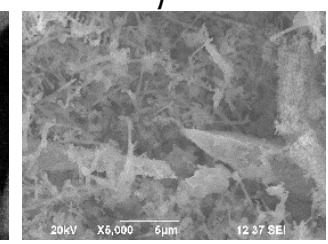

j



$n$

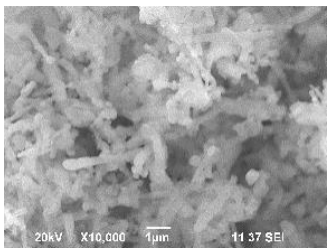

$q$

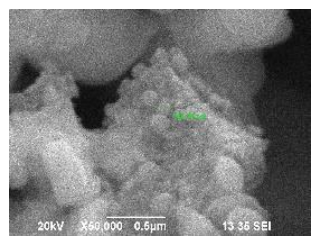

c



$g$

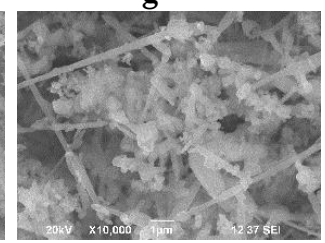

$k$

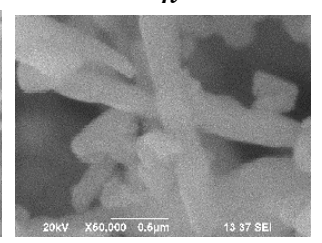

O

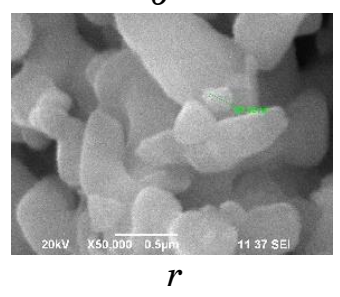

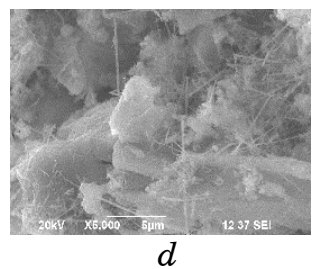

$d$

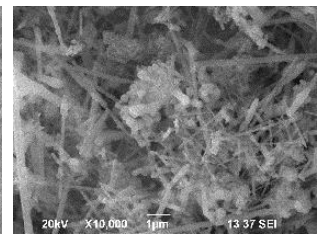

h

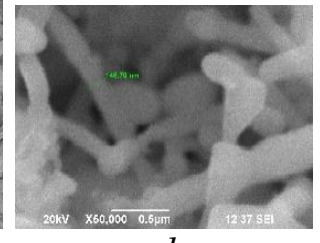

$l$

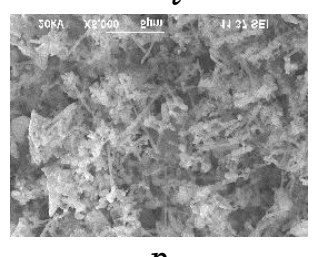

$p$

Fig. 4. SEM micrographs at various magnification of obtained carbides at different temperatures: $a-c-1400^{\circ} \mathrm{C}, d-f-1500^{\circ} \mathrm{C}, g-i-1600^{\circ} \mathrm{C}, j-l-1700^{\circ} \mathrm{C}$, $m-o-1800^{\circ} \mathrm{C}, p-r-1900^{\circ} \mathrm{C}$. 
oxide. At $1600^{\circ} \mathrm{C}$ and higher temperatures, it is found that the $\mathrm{Si}-\mathrm{O}-\mathrm{Si}$ stretching and anti-stretching vibration peaks have disappeared, which signifies complete transformation $\mathrm{SiO}_{2}$ to $\mathrm{SiC}$.

The SEM images of the all synthesized $\mathrm{SiC}$ at various magnifications are compared in Fig. 4, and these were verified to be $\mathrm{SiC}$ particles by EDS (Fig. 5). The EDS results further confirm the formation of a SiC and are in good agreement with the XRF, XRD and FTIR-ATR analysis. Moreover, it is clear that samples are composed of SiC crystals together with $\mathrm{SiC}$ whiskers that are homogenously distributed and randomly oriented. At lower temperature $1500^{\circ} \mathrm{C}$, because of the lower reaction rate, $\mathrm{SiC}$ whiskers were rare, as shown in Fig. $4, d-f$. However, whiskers were generally a few micrometres in length and 60-200 $\mathrm{nm}$ in diameter. The diameter of the whiskers increased with increasing temperatures. It is unambiguous that $\mathrm{SiC}$ whiskers were formed at 1500$1900^{\circ} \mathrm{C}$, while the lengths decrease and quantities increase with the
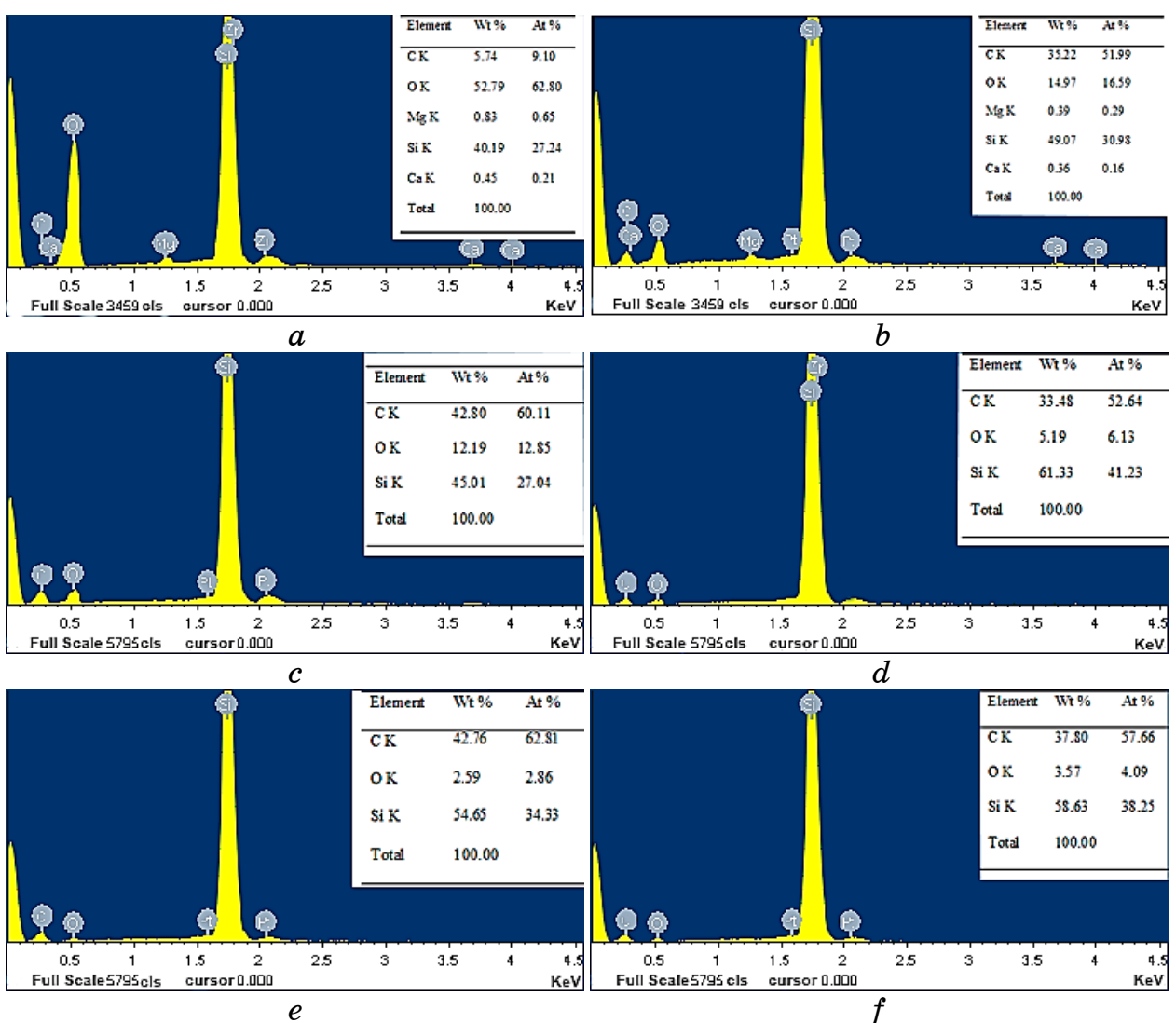

Fig. 5. EDS analysis of obtained carbides at different temperatures: $a-$ $1400^{\circ} \mathrm{C}, b-1500^{\circ} \mathrm{C}, c-1600^{\circ} \mathrm{C}, d-1700^{\circ} \mathrm{C}, e-1800^{\circ} \mathrm{C}, f-1900^{\circ} \mathrm{C}$. 
TABLE 3. Specific surface area, $S_{\mathrm{BET}}$, total pore volume, $V_{t}$, and pore dimensions, $D$, of the samples.

\begin{tabular}{c|c|c|c}
\hline Obtained at, ${ }^{\circ} \mathrm{C}$ & $S_{\mathrm{BET}}, \mathrm{m}^{2} / \mathrm{g}$ & $V_{t}, \mathrm{~cm}^{3} / \mathrm{g}$ & $D, \mathrm{~nm}$ \\
\hline 1400 & 4.3 & 0.013 & 3.30 \\
1500 & 11.5 & 0.031 & 5.84 \\
1600 & 11.0 & 0.023 & 3.32 \\
1700 & 3.1 & 0.006 & 6.78 \\
1800 & 1.8 & 0.004 & 20.12 \\
1900 & 4.1 & 0.005 & 4.56 \\
\hline
\end{tabular}

rise in temperature (Fig. $4, d-s$ ). These depend on the reaction pathway for the $\mathrm{SiC}$ formation [16]. Obviously, the coating surface is very rough, and some cracks and holes can be found too, indicating the formation of a porous structure. These defects offer the diffusion channels for oxygen to attack the substrate and may lead to the degradation of the oxidation protective ability of the coating. As per the EDS of the area shown in Fig. 5, $c-f$, the main elements of the layer are $\mathrm{Si}, \mathrm{C}$ and $\mathrm{O}$, which indicates that $\mathrm{SiC}$ has been oxidized [17] or a small amount of unreacted silica remained [18]. The presence of Pt in the EDS spectra is the signature of $\mathrm{Pt}$ grid used for mounting the powder samples.

Table 3 provides data on the specific surface area (BET), total pore volume and pore dimensions of the samples obtained at $1400-1900^{\circ} \mathrm{C}$. It can be seen that with increasing temperatures samples have a wide range of pore dimensions and thus low specific surface area.

\section{CONCLUSION}

$\beta$-Silicon carbide particles and whiskers were prepared by direct carbothermal reduction of bio- $\mathrm{SiO}_{2}$ and activated carbon. In addition, the mixture was heat treated at various temperatures. The minimum temperatures that the mixture was almost converted to silicon carbide for a shorter holding time of $1 \mathrm{~h}$ was $1700^{\circ} \mathrm{C}$. EDX analysis of obtained particles and whiskers observed by SEM confirms the presence of $\mathrm{Si}$ and $\mathrm{C}$, indicating the presence of $\mathrm{SiC}$.

\section{ACKNOWLEDGEMENTS}

The catalytic experiments and laboratory installation assembling have been funding by Target Complex Program of Scientific Research of N.A.S. of Ukraine from the development of scientific principles of rational use of natural resource potential and sustainable development, project 14, 2015-2019. 


\section{REFERENCES}

1. Y.P.Simonenko, Novyye Podkhody $k$ Sintezu Tugoplavkikh Nanokristallicheskikh Karbidovi Oksidov i Polucheniyu Ul'travysokotemperaturnykh Keramicheskikh Materialov na Osnove Diborida Gafniya [New Approaches to the Synthesis of Refining Nanocrystalline Carbides and Oxides and Production of Ultra-Temperature Ceramic Materials Based on Hafnium Diboride] (Disser. for Dr. Chem. Sci.) (Moscow: N. S. Kurnakov Institute of General and Inorganic Chemistry, R.A.S.: 2016) (in Russian).

2. V. A. Karelin, A. N. Strashko, A. V. Sazonov, and A. V. Dubrovin, ResourceEfficient Technologies, 2: 50 (2016); https://doi.org/10.1016/j.reffit.2016.06.002.

3. M. Usman, Impact of Ionizing Radiation on 4H-SiC Devices (Dr. Thesis for Teknologie Dr.) (Stockholm: Microelectronics and Applied Physics School of Information and Communication Technology (ICT) KTH Royal Institute of Technology: 2012).

4. J. Fan and P. K. Chu, Silicon Carbide Nanostructures (Switzerland: Springer International Publishing: 2014); https://doi.org/10.1007/978-3-319-087269_2.

5. M. Neumann, R. Noske, A. Taubert, B. Tierscha, and P. Strauch, J. Mater. Chem., 22: 9046 (2012); https://doi.org/10.1039/C2JM30253E.

6. H. Yan, B. Wang, X. M. Song, L. W. Tan, S. J. Zhang, G. H. Chen, S. P. Wong, R. W. M. Kwok, and W. M. L. Leo, Diam. Relat. Mater., 9: 1795 (2000); https://doi.org/10.1016/S0925-9635(00)00308-3.

7. O. A. Ageyev, A. Ye. Belyayev, N. S. Boltovets, B. C. Kiselev, R. V. Konakova, A. A. Lebedev, V. V. Milenin, O. B. Okhrimenko, V. V. Polyakov, A. M. Svetlichnyy, and D. I. Cherednichenko, Karbid Kremniya: Tekhnologii, Svoystva, Primenenie (Kharkov: ISMA: 2010) (in Russian).

8. L. G. Ceballos-Mendivil, R. E. Cabanillas-Lypez, J. C. Tánori-Cyrdova, R. Murrieta-Yescas, P. Zavala-Rivera, and J. H. Castorena González, Energy Procedia, 57: 533 (2014); https://doi.org/10.1016/j.egypro.2014.10.207.

9. M. K. Trivedi, G. Nayak, R.M . Tallapragada, S. Patil, O. Latiyal, and S. Jana, J. Powder Metall. Min., 4: 1 (2015); http://dx.doi.org/10.4172/21689806.1000132.

10. Voo Chung Sung Tony, Chun Hong Voon, Chang Chuan Lee, Bee Ying Lim, Subash Chandra Bose Gopinath, Kai Loong Foo, Mohd Khairuddin Mohd Arshad, Abdul Rahim Ruslinda, Uda Hashim, Mohd Nordin Nashaain, and Yarub Al-Douri, Materials Research., 20: 6 (2017); http://dx.doi.org/10.1590/1980-5373-MR-2017-0277.

11. S. L. Shikunov and V. N. Kurlov, Technical Physics, 62: 12 (2017); http://dx.doi.org/10.1134/S1063784217120222.

12. T. Aichingera, G. Rescherb, and G. Pobegen, Microelectronics Reliability, 80: 68 (2018); https://doi.org/10.1016/j.microrel.2017.11.020.

13. V. A. Yevdokymenko, D. S. Kamenskyh, V. I. Kashkovsky, and V. V. Vakhrin, Method of Producing Amorphous Silicon Dioxide from the Rice Husk (Patent 117881 UA. MKI B01J 19/24 C01B 33/00 C01B 33/023 (Bul. No. 18) (2018)) (in Ukrainian).

14. Thanh Nhan Tran, Thi Van Anh Pham, My Loan Phung Le, Thi Phuong Thoa Nguyen, and Van Man Tran, Adv. Nat. Sci.: Nanosci. Nanotechnol., 4: 1 (2013); 
https://doi.org/10.1088/2043-6262/4/4/045007.

15. Yo. Li, Ch. Chen, Ji.-T. Li, Yu. Yang, and Zh.-M. Lin, Nanoscale Res. Lett., 6: 454 (2011); https://doi.org/10.1186/1556-276X-6-454.

16. Ye Hua, Shuxin Bai, Hong Wan, Xingyu Chen, Ting Hu, and Jinyu Gong, J. Mater Sci., 54: 2016 (2019); https://doi.org/10.1007/s10853-018-3016-7.

17. Yangn Xiang, Luming Huang, and Zhaohui Chen, Ceram. Int., 40: 10303 (2014); https://doi.org/10.1016/j.ceramint.2014.03.001.

18. T. S. Kvashina, Yu. L. Krutskii, N. Yu. Cherkasova, R. I. Kuzmin, A. G. Tyurin, Doklady Akademii Nauk Vysshei Shkoly Rossiiskoi FederatsiiProceedings of the Russian Higher School Academy of Sciences, No. 4 (37): 80 (2017) (in Russian); https://doi.org/10.17212/1727-2769-2017-4-80-90. 